\title{
Natriuretic hormone-its possible role in fluid and electrolyte disturbances in chronic liver disease
}

\author{
HERBERT J. KRAMER \\ M.D. \\ Medizinische Universitäts-Poliklinik, Bonn, Germany
}

\begin{abstract}
Summary
Besides intrarenal physical factors and aldosterone, a natriuretic hormone has been postulated to modulate renal tubular sodium resorption in order to maintain body fluid homeostasis. To investigate the possible role of a natriuretic activity in sodium retention of chronic liver disease, the effects of plasma and plasma fraction IV from patients with cirrhosis of the liver and ascites on sodium transport of the isolated frog skin and on renal sodium excretion in the rat were compared to the antinatriferic and natriuretic effects of plasma from healthy subjects. While plasma from healthy individuals obtained following acute expansion of the extracellular fluid volume (ECV) significantly inhibited potential difference (PD) by $-\mathbf{4 3 . 8} \pm \mathbf{5 . 5} \%$ and short circuit current (SCC) by $-\mathbf{4 1 . 3} \pm 1.7 \%$ when applied to the inner skin surface, control plasma and plasma from patients with liver cirrhosis and ascites affected PD by $-\mathbf{3 . 8} \pm \mathbf{4 . 7} \%$ and $-\mathbf{5 . 2} \pm$ $3.7 \%$ and SCC by $-\mathbf{7 . 3} \pm \mathbf{4 . 6} \%$ and $-\mathbf{1 1 . 7} \pm \mathbf{2 . 5} \%$ respectively.

Similar effects on PD and SCC were observed with plasma fractions IV.

In contrast to fraction IV from ECV-expanded individuals, which caused marked diuresis and natriuresis when injected in the rat, fraction IV of plasma from cirrhotic patients failed to affect urinary flow rate, free-water clearance or renal sodium excretion. The results suggest that at least some patients with cirrhosis of the liver and sodium retention may lack an adequate humoral natriuretic activity sufficiently to promote renal sodium excretion.
\end{abstract}

\section{Introduction}

In chronic liver disease, abnormal retention of salt and water with limited natriuretic response to sodium load (Goodyer et al., 1950) is ascribed to impaired renal function, eventually leading to progressive oliguric renal failure. Although a recent report suggests that enhanced distal tubular sodium resorption is primarily responsible for fluid retention in some

Reprint requests to Prof. Dr Herbert J. Kramer, Medizinische Universitäts-Poliklinik, 53 Bonn 1, Wilhemstrasse 35-37, West Germany. patients with liver disease (Chaimovitz et al., 1972), avid proximal tubular sodium resorption has been incriminated on the basis of previous observations on renal sodium and free-water clearance in these patients (Baldus et al., 1964a; Summerskill, 1966; Vesin, 1972).

While the roles of aldosterone (Wolff et al., 1966) and of intrarenal physical factors (Schrier and de Wardener, 1971) in salt and water homeostasis are well established and, by enhancing distal and proximal tubular sodium resorption, appear to be predominantly responsible for avid salt retention in advanced chronic liver disease, antidiuretic hormone does not seem to play an important role with respeci to impaired water balance observed in hepatic failure (Vaamonde et al., 1971). Additional factors however, must be evoked to explain positive sodium balance already noted during the early course of chronic liver disease (stage I according to Vesin, 1972) when renal blood flow, glomerular filtration rate and filtration fraction (Vesin, 1972), peritubular hydrostatic and oncotic pressure may be normal.

In addition, the enhanced proximal tubular sodium resorption in chronic liver disease, may depend on a yet unidentified humoral factor. To investigate this hypothesis in the present study, the effects of plasma and plasma fraction IV from patients with cirrhosis of the liver and ascites on sodium transport of the isolated frog skin and on renal sodium excretion in the rat were studied. They were compared to the effects of plasma from healthy individuals and of plasma fraction IV previously shown to contain the antinatriferic and natriuretic activity present in plasma from ECV expanded subjects.

\section{Materials and methods}

Six healthy human subjects were infused intravenously with 1 litre of isotonic Ringer solution within 30 min followed by 2 litres of Ringer solution administered during the next $2 \mathrm{hr}$. Fifty millilitres of venous blood were drawn before and at the end of each study. Plasma samples are subsequently designated as control and natriuretic plasma respectively.

From seven patients with cirrhosis of the liver, six 
TABLE 1. Body weight before and after diuretic therapy and blood chemistry on admission of patients with liver cirrhosis

\begin{tabular}{|c|c|c|c|c|c|c|c|c|c|c|}
\hline \multirow[b]{3}{*}{ Patient } & \multirow[b]{3}{*}{$\begin{array}{c}\text { Age } \\
\text { (years) }\end{array}$} & \multicolumn{2}{|c|}{ Body weight } & \multirow{2}{*}{\multicolumn{7}{|c|}{ Serum }} \\
\hline & & & & & & & & & & \\
\hline & & $\begin{array}{l}\text { therapy } \\
(\mathrm{kg})\end{array}$ & $\begin{array}{l}\text { therapy } \\
(\mathrm{kg})\end{array}$ & $\underset{(\mathrm{mEq} / 1)}{\mathrm{Na}}$ & $\underset{(m E q / l)}{K}$ & $\begin{array}{c}\text { BUN } \\
(\mathrm{mg} \%)\end{array}$ & $\begin{array}{c}\text { Albumin } \\
(\mathrm{g} \%)\end{array}$ & $\begin{array}{l}\text { Bilirubin } \\
(\mathrm{mg} \%)\end{array}$ & $\begin{array}{c}\text { SGOT } \\
(\mathrm{mu} / \mathrm{ml})\end{array}$ & $\begin{array}{c}\text { Prothrombin } \\
(\%)\end{array}$ \\
\hline Ru. & 49 & $68 \cdot 0$ & 56.4 & 140 & $4 \cdot 7$ & 24 & $2 \cdot 6$ & $3 \cdot 0$ & 34 & 46 \\
\hline Wa. & 62 & $77 \cdot 4$ & $66 \cdot 9$ & 137 & $4 \cdot 4$ & 28 & $1 \cdot 8$ & $3 \cdot 6$ & 140 & 44 \\
\hline Ko. & 61 & $57 \cdot 5$ & $47 \cdot 0$ & 140 & $2 \cdot 6$ & 23 & $2 \cdot 8$ & $8 \cdot 2$ & 27 & 39 \\
\hline Sch. & 63 & $96 \cdot 9$ & $87 \cdot 2$ & 139 & $5 \cdot 2$ & 23 & $3 \cdot 8$ & 0.7 & 34 & 86 \\
\hline $\mathrm{K} 1$. & 60 & $65 \cdot 0$ & 50.6 & 137 & $4 \cdot 4$ & 36 & $2 \cdot 2$ & $1 \cdot 0$ & 24 & 74 \\
\hline Ba. & 50 & $53 \cdot 1$ & $47 \cdot 3$ & 124 & $3 \cdot 2$ & 25 & $2 \cdot 6$ & $3 \cdot 7$ & 58 & 52 \\
\hline $\mathrm{Bu}$. & 52 & $82 \cdot 5$ & $79 \cdot 5$ & 142 & $3 \cdot 8$ & 22 & $3 \cdot 0$ & $1 \cdot 1$ & 53 & 60 \\
\hline
\end{tabular}

with ascites and peripheral oedema and one (Bu.) without clinical manifestation of fluid retention, blood was drawn before initiation of therapy. Fluid retention was estimated from weight loss during diuretic therapy at the time when body weight had stabilized in the absence of demonstrable ascites. The diagnosis of cirrhosis of the liver was based on previous history, physical examination, blood chemistry (Table 1) and histological examination.

Blood samples were immediately placed in ice and centrifuged at $4^{\circ} \mathrm{C}$. Plasma was frozen stored at $-18^{\circ} \mathrm{C}$. Plasma samples $(10 \mathrm{ml})$ were fractionated by column chromatography using Sephadex G-25 as reported by Kramer, Gospodinov and Krück (1974). Single fractions pooled to fraction IV (Fig. 1) were lyophilized and the resulting powder was stored at $-18^{\circ} \mathrm{C}$. The effects of plasma and plasma fraction IV on PD and SCC of the isolated abdominal skin
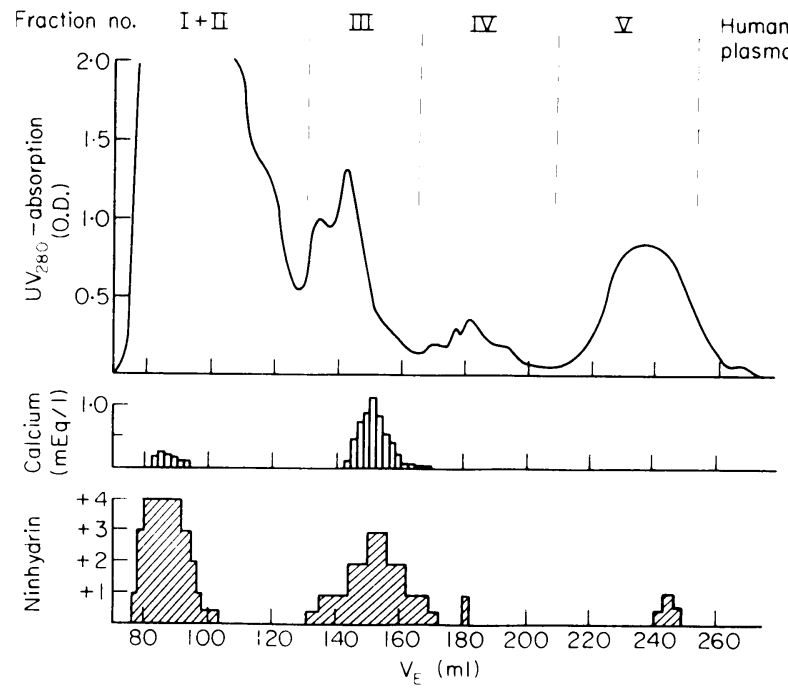

FIG. 1. Fractionation patterns of human plasma following gelfiltration through Sephadex G-25. Presented are $\mathrm{UV}_{289}$-absorption, ninhydrin reaction and calcium concentrations of single fractions subsequently pooled to fractions I to $\mathrm{V}$. of the frog, Rana temporaria, were investigated as described by Kramer et al. (1974).

To study natriuretic activity of plasma fraction IV, female Sprague Dawley rats weighing approximately $250 \mathrm{~g}$ with previously free access to food and water were employed. Under light ether anaesthesia, a polyethylene catheter (PE 50) was inserted into the jugular vein and an additional catheter (PE 90) was placed transabdominally into the urinary bladder. The animals were then placed in single restraining cages. After i.v. injection of $2 \mathrm{ml}$ of isotonic saline to replace volume loss during surgery, an infusion of $2.5 \%$ glucose solution was started to maintain body weight constant throughout the experiment. One hour after surgery was completed, when urinary flow rate and sodium excretion had stabilized, $0.5 \mathrm{ml}$ of lyophilized and ten-fold concentrated plasma fractions IV reconstituted with distilled water $(\mathrm{pH} \mathrm{7 \cdot 2)}$ or $0.5 \mathrm{ml}$ of $2.5 \%$ glucose solution were injected i.v. followed by four to six $15-\mathrm{min}$ urine collection periods.

Concentrations of sodium and potassium were determined by flame photometry. A Beckman $\mathrm{pH}$ micro-electrode was used for $\mathrm{pH}$ determination and an advanced osmometer was used for osmolality determination. Glomerular filtration rate was measured as described by Kramer and Gonick (1974). The results were analysed statistically using double tail Student's $t$-test. Data are presented as mean s.e. mean.

\section{Results}

The effects of plasma from six healthy human subjects obtained before and after acute expansion of the ECV on PD and SCC of the isolated frog skin are summarized in Fig. 2. The Ringer solution bathing the inside surface of the skin was replaced by $10 \mathrm{ml}$ of post-expansion plasma, then an immediate fall in PD and SCC was noted, while control plasma had no significant effect. After 60 min, mean changes in PD and SCC by control plasma were $-3.8+4.7 \%$ and $-7 \cdot 3+4.6 \%$, respectively, whereas natriuretic plasma depressed PD by $-43 \cdot 8 \pm 5 \cdot 5 \%$ and SCC by 
TABLF 2. Effects of plasma from patients with liver cirrhosis and ascites on potential difference (PD) and short-circuit current (SCC) of isolated frog skin as compared to the effects of plasma from control subjects before and after ECV expansion

\begin{tabular}{|c|c|c|c|c|c|c|c|}
\hline \multirow[b]{3}{*}{ Patient } & \multicolumn{4}{|c|}{ Controls } & \multirow{2}{*}{\multicolumn{3}{|c|}{$\begin{array}{c}\text { Patients with cirrhosis of the } \\
\text { liver and ascites }\end{array}$}} \\
\hline & \multicolumn{2}{|c|}{ Pre-expansion } & \multicolumn{2}{|c|}{ Post-expansion } & & & \\
\hline & PD & SCC & PD & SCC & Patient & PD & $\mathrm{SCC}$ \\
\hline $\mathrm{Na}$. & +16 & +4 & -44 & -38 & Ru. & -14 & -17 \\
\hline Go. & -2 & 0 & -46 & -48 & Wa. & -14 & -16 \\
\hline Po. & -14 & -25 & -34 & -36 & Ko. & -7 & 0 \\
\hline Go. & -8 & +1 & -29 & -43 & Schw. & +10 & -12 \\
\hline $\mathrm{Si}$. & 0 & -16 & -68 & -40 & $\mathrm{~K} 1$. & 0 & -13 \\
\hline Sp. & -5 & -8 & -42 & -43 & Ba. & -6 & -12 \\
\hline Mean & $-3 \cdot 8$ & $-7 \cdot 3$ & $-43 \cdot 8^{*}$ & $-41 \cdot 3^{*}$ & & $-5 \cdot 2$ & $-11 \cdot 7$ \\
\hline s.e. & $4 \cdot 7$ & $4 \cdot 6$ & $5 \cdot 5$ & $1 \cdot 7$ & & $3 \cdot 7$ & $2 \cdot 5$ \\
\hline
\end{tabular}

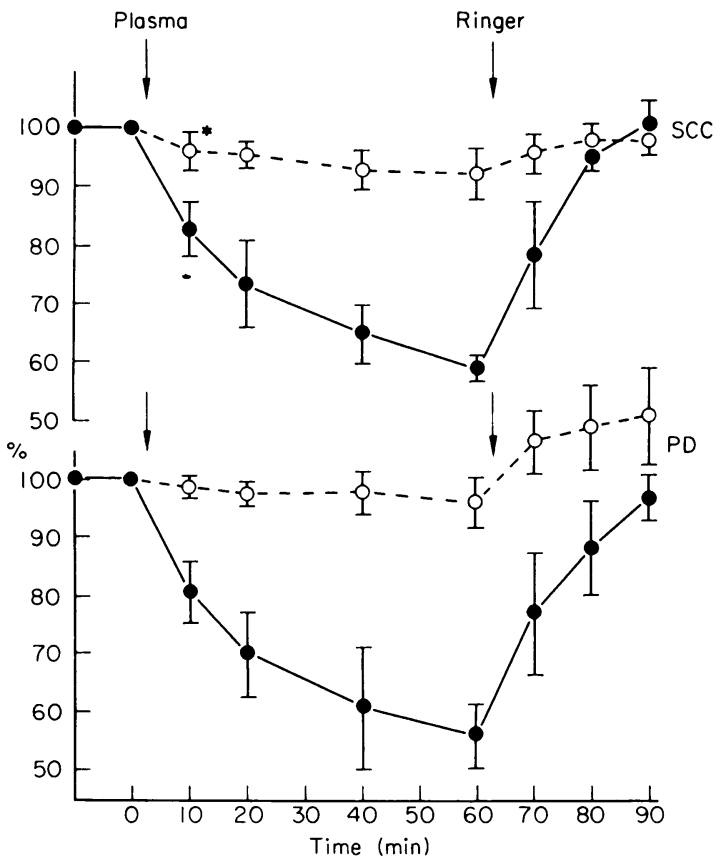

FIG. 2. Mean decrease in PD and SCC of the isolated frog skin following addition of plasma from healthy subjects obtained before and after acute ECV-expansion. The inhibition of sodium transport is reversible when plasma is replaced by fresh Ringer solution. $\mathrm{O}$-.. $\mathrm{O}$, Pre-expansion; - post-expansion. */ s.e.

$-41 \cdot 3 \pm 1 \cdot 7 \% \quad(P<0.001)$. This inhibition of sodium transport was completely reversible when plasma was replaced by fresh Ringer solution. To study reproducibility and stability of the antinatriferic activity during storage, identical plasma samples were assayed after 6 weeks and 6 months of storage at $-18^{\circ} \mathrm{C}$. As shown in Fig. 3, a small time-dependent decrease of the effect of natriuretic plasma on

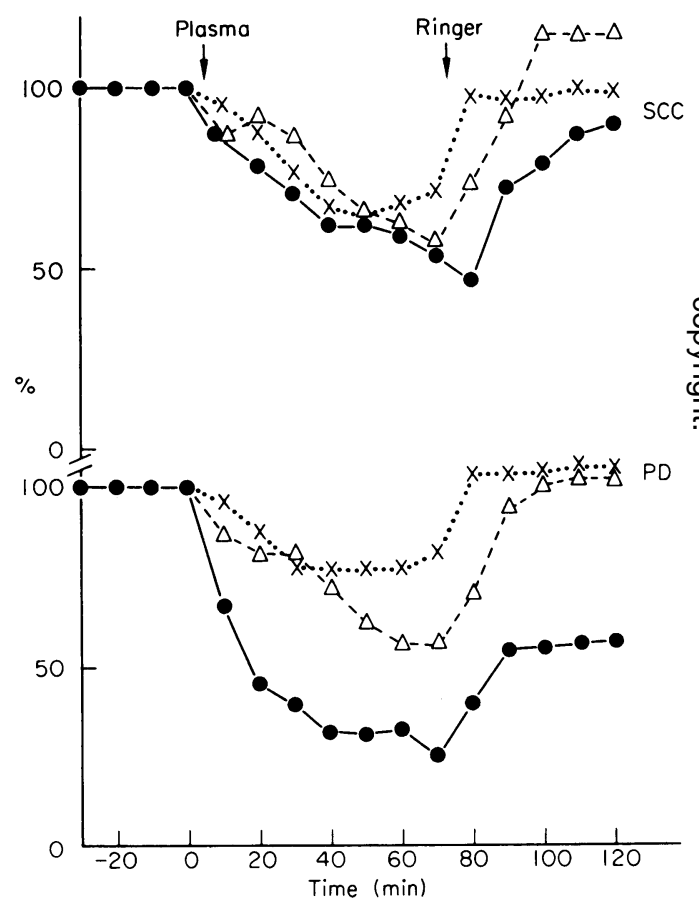

FIG. 3. Reproducibility and stability of antinatriferic plasma activity after storage at $-18^{\circ} \mathrm{C}$ for various intervals of time. - , Within 1 week; $\triangle \cdots \triangle$, after 6 weeks; $\times \ldots . . \times$, after 6 months.

SCC was noted, while a more pronounced and progressive loss of inhibition of PD resulted.

As compared to the effects of natriuretic plasma, plasma from patients with liver cirrhosis and ascites had no significant antinatriferic effect (Table 2). Sixty minutes after replacement of Ringer solution by plasma from patients with liver cirrhosis, mean changes of PD of $-5 \cdot 2 \pm 3.7 \%$ and of SCC of $-11 \cdot 7 \pm 2.5 \%$ were not significantly different from 


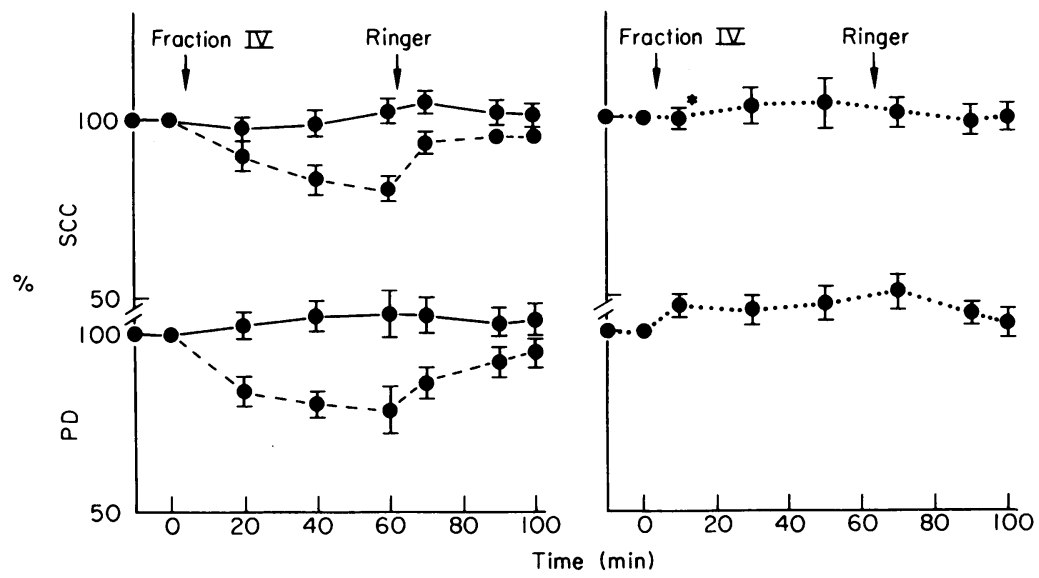

FIG. 4. Mean changes in PD and SCC of isolated frog skin induced by fraction IV of plasma from healthy subjects before and after ECV-expansion and from patients with liver cirrhosis and ascites when added to the Ringer solution bathing the inner surface. - - , controls; -.- . ECV-expansion; O..... , cirrhotics. */ s.e., $n=6$ (number of subjects).

the effects of control plasma. In contrast, the only patient $\mathrm{Bu}$.) without clinical evidence of ascites or oedema revealed an adequate antinatriferic plasma activity with inhibition of PD by $44 \%$, and of SCC by $47 \%$.

Similar results were obtained when lyophilized plasma fractions IV were added to the Ringer solution bathing the inner surface of the skin (Fig. 4). Again fraction IV derived from natriuretic plasma markedly inhibited PD and SCC, while control fraction IV had no significant effect. No inhibitory activity on sodium transport of the isolated skin was observed when fraction IV of plasma from patients with cirrhosis and ascites was added to Ringer solution (Fig. 4).

When $0.5 \mathrm{ml}$ of reconstituted plasma fractions IV from cirrhotic patients with ascites, corresponding to $5.0 \mathrm{ml}$ of original plasma, were injected i.v. into Sprague Dawley rats, no significant increase in sodium excretion was observed when compared to two preceding urine collections taken during continuous infusion of $2.5 \%$ glucose solution to maintain a constant body weight. With one exception, urinary flow rate and potassium excretion slightly decreased following injection of fraction IV (Fig. 5). Figure 6 summarizes the changes in urinary flow rate, freewater clearance, and sodium and potassium excretion during the first 15 -min collection period after injection of $0.5 \mathrm{ml}$ of plasma fractions IV-corresponding to $5.0 \mathrm{ml}$ of original plasma activity-from healthy subjects before and after acute ECV expansion and from cirrhotic patients with ascites. While control fraction IV did not significantly alter urinary water and electrolyte excretion, fraction IV of natriuretic plasma markedly enhanced urinary flow rate, free-water clearance, and sodium excretion. Fraction IV of plasma from cirrhotic patients revealed a similar lack of natriuretic activity as did control fraction IV.

\section{Discussion}

Mounting evidence suggests that the liver participates directly or indirectly in the humoural regulation of body homeostasis which, for example, includes metabolism of histamine, glucocorticoids, and catecholamines. With special regard to salt and water homeostasis, this regulatory function comprises metabolism or renin (Heacox, Harvey and Vander, 1967; Wernze et al., 1972), aldosterone (Wolff et al., 1966), and ADH (Lauson, 1967), thereby influencing renal salt and water excretion. The liver is also involved in the production or stimulation of diuretic activity (Haberich et al., 1965; Milies, 1960), which suggests its osmoregulatory role in body fluid balance (Wollheim, 1961). Furthermore, it has been suggested that the liver synthesizes a vasodepressor which regulates cardiorenal function (Baez, Mazur and Shorr, 1950); it may also play a role in the maintenance of normal renal viability (Mondon, Burton and Ishida, 1969). Thus, ample evidence can be presented for an intimate metabolic and functional interrelationship between these two organs.

Since consistent histopathological alterations of the kidney in hepatic failure have not been observed (Papper, 1973; Salomon et al., 1965), kidneys grafted from patients with chronic liver disease regain normal function (Koppel et al., 1969), and spontaneous recovery of renal function in liver cirrhosis has been repeatedly reported (Goldstein and Boyle, 


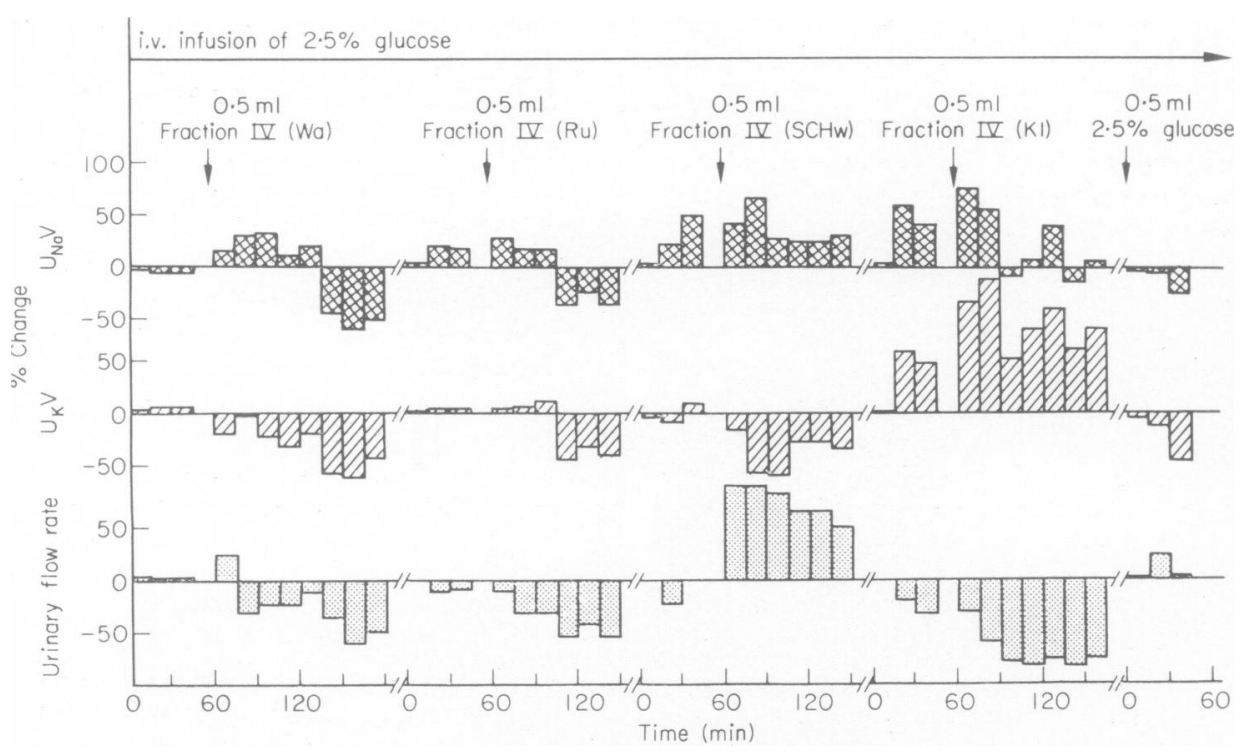

FIG. 5. Representative time sequence of changes in urinary flow rate, and renal sodium and potassium excretion in rats following i.v. injection of $0.5 \mathrm{ml}$ of reconstituted plasma fraction IV from patients with liver cirrhosis and ascites.

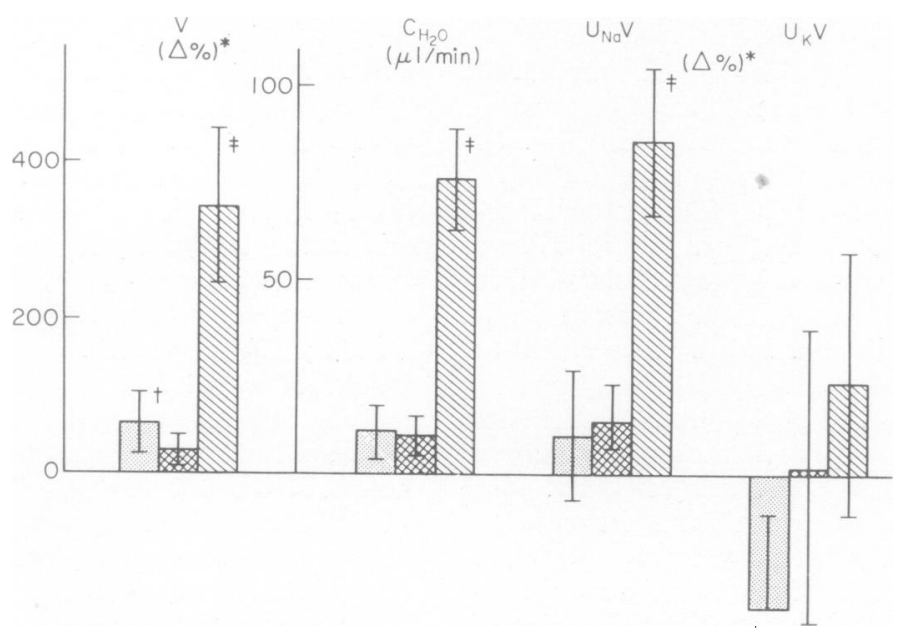

Fig. 6. Mean changes in urinary flow rate, free-water clearance, and sodium and potassium excretion in the rat $15 \mathrm{~min}$ after i.v. injection of fraction IV of control and natriuretic plasma from healthy subjects and of plasma from patients with liver cirrhosis and ascites. $\mathbb{N}$, acute ECV-expansion $(n==7) . * / \%$ change from baseline, $\dagger /$ s.e.; $\neq / P<0.05$.

1965; Pecikyan, Kanzaki and Berger, 1967), renal impairment seems a reversible functional abnormality.

Primarily, haemodynamic circulatory alterations have been evoked as responsible factors of enhanced sodium resorption in liver disease, i.e. decreased renal blood flow (Epstein et al., 1970) resulting from reduced or shunted 'effective' intravascular volume (Tristiani and Cohn, 1967; Papper and Vaamonde,
1968) in the presence of elevated total plasma volume (Lieberman, Ito and Reynolds, 1969; Lieberman and Reynolds, 1967; McCloy et al., 1967) and high cardiac output (Papper, 1973). In addition, increased renal vascular resistance (Baldus et al., 1964b), probably at the afferent arteriolar level, and increased peritubular oncotic pressure resulting from increased filtration fraction (Summerskill, 1966; 
Traverso et al., 1966) have been observed, although the latter may be counteracted by hypoalbuminaemia associated with chronic hepatic failure (Brenner \& Troy, 1971). Finally, the role of abnormal distribution of renal blood flow with preferential juxtamedullary and medullary perfusion in patients with liver cirrhosis has recently been emphasized (Schröder et al., 1967).

Since the early 1960s, several groups of investigators have presented evidence favouring the existence of a humoral natriuretic factor (de Wardener et al., 1961) which, in addition to known determinants such as glomerular filtration and circulating aldosterone activity (Smith, 1957), can inhibit tubular sodium resorption in the rat (Brown, Koutsaimanis and de Wardener, 1972; Kramer et al., 1974; Sealey et al., 1971), PAH (Bricker et al., 1968) and sodium transport by slices of rabbit kidney (Robson et al., 1969) and sodium transport by isolated biological membranes (Buckalew, Martinez and Green, 1970; Clarkson and de Wardener, 1972; Kramer and Gonick, 1974; Kramer et al., 1974).

In the present study, plasma and plasma fraction IV obtained from healthy subjects following acute expansion of the extracellular fluid compartment significantly inhibited PD and SCC of the isolated skin of Rana temporaria. This inhibition of sodium transport was completely reversible when natriuretic plasma was replaced by Ringer solution. In contrast, plasma and plasma fraction IV from most patients with liver cirrhosis and ascites did not significantly alter PD or SCC indicating a similar lack of antinatriferic activity as was noted with plasma from healthy subjects before ECV expansion and, as previously reported, with plasma from patients with the nephrotic syndrome and excessive extracellular fluid retention due to oedema formation (Kramer et al., 1974). In the rat bioassay no significant natriuresis was observed following i.v. administration of plasma fraction IV from cirrhotic patients. Mean changes in urinary flow rate, free-water clearance and sodium excretion were similar to those noted after injection of control fraction IV, while fraction IV derived from natriuretic plasma markedly increased urinary output, free-water clearance and sodium excretion in the absence of changes in GFR (Kramer et al., 1974). Thus, it seems that at least some patients with cirrhosis of the liver and ECV expansion have no antinatriferic and natriuretic plasma activity or, if they do, it is inordinately low, when compared to the humoural activity demonstrated in healthy subjects following expansion of the extracellular fluid volume.

Studies from this laboratory have recently shown that this natriuretic activity can be ascribed to one plasma fraction IV obtained by gelfiltration with Sephadex G-25 (Kramer et al., 1974).

On the basis of gelfiltration studies and passage through Ultraflo ${ }^{\circledR}$ membranes the active compound has an estimated molecular weight of 1000 (Kramer, Gonick and Krück, 1972; Kramer et al., 1969). It is inactivated by incubation with chymotrypsin while resistant to trichloracetic acid. This fraction was also shown significantly to inhibit renal Na-K-ATPase in vitro (Kramer, 1972; Kramer et al., 1969) and to possess saluretic activity in the rat bioassay (Kramer et al., 1974), where increased excretion of sodium and the increase in free-water clearance suggest an inhibitory action on proximal tubular sodium resorption.

With respect to the possible role of such a natriuretic activity in liver disease, the key question arises of where the hypothetical hormone originates. Although so far only conflicting results have been reported, essentially two organs besides the kidney itself (Mills, Wilson and de Bono, 1971) have been implicated as possible sources: the hypothalamic area or posterior pituitary gland, and the liver. These implications are based on indirect evidence from infusion studies, on bioassay studies of natriuretic activity derived from blood leaving various organs, and on organ ablation. Thus, Cirkensa, Dirks and Berliner (1966) concluded from their experiments in the caval dog that a humoral natriuretic substance might be released from the liver. Daly, Roe and Horrocks (1967), infusing $5 \%$ saline into the femoral and portal vein, observed a significantly greater natriuretic response from the portal vein. This was confirmed by Strandhoy and Williamson (1970) when infusion of saline into the portal vein of group I and into the right atrium of group II animals gave a similar natriuretic effect but with a higher baseline sodium excretion in group II. The authors conclude from their data that the liver may be involved in the regulation of renal sodium excretion. More direct evidence on the basis of bioassay data was presented by Stahl et al. (1967), who found a natriuretic and diuretic activity first appearing in hepatic venous blood of volume-expanded dogs and humans. Investigating the natriuretic effects of various organ extracts in the rat, Sealey and Laragh (1971) also observed maximum natriuretic activity being present in tissue extracts of the liver.

Therefore, if a natriuretic humoral factor would be generated or released by the liver in response to changes in extracellular fluid volume, failure of renal sodium excretion in liver disease could then easily be related to the metabolic and functional impairment of this organ.

Alternatively, the demonstration of natriuretic activity isolated from blood leaving the brain suggests that this organ is the site of origin. Thus, Cort et al. (1968) and Buckalew et al. (1970) observed maximum natriuretic activity in jugular venous blood and, recently, Gitelman and Blythe (1972), 
Quamme, Dirks and Friesen (1973), and Robinson et al. (1973) demonstrated natriuretic activity in tissue extracts of hypothalamus and posterior pituitary gland. On the basis of organ ablation, however, Levinsky (1966) concluded that a natriuretic factor is secreted neither from the brain nor the liver.

If, therefore, the liver itself would not release or stimulate the release of a natriuretic factor, how then can the lack of natriuretic response in liver disease (Goodyer et al., 1950), despite an excessive retention of salt and water, be explained if we accept the hypothesis that a humoral factor participates in proximal tubular resorption of sodium? At this point it seems appropriate to consider an analogous experimental model associated with the formation of ascites. Following constriction of the thoracic inferior vena cava in the dog, which causes marked ascites, the natriuresis usually associated with ECV expansion is almost completely blunted (Cirkensa et al., 1966; Pearce and Sonnenberg, 1965). This is due to avid sodium resorption in the proximal tubule (Cirkensa et al., 1966) as well as to enhanced sodium absorption in the diluting segment of Henle's loop and the distal site of $\mathrm{Na}-\mathrm{K}$ exchange (Kaloyanides et al., 1969). Under comparable experimental conditions, Kaloyanides and Azer (1972) and Buckalew and Lancaster (1971) also failed to demonstrate a humoral activity previously observed in ECV expansion (Buckalew et al., 1970). A similar effect was demonstrated during constriction of the superior vena cava (Schrier et al., 1971) but was not achieved following abdominal cava constriction although leading to an equal rise in renal venous pressure (Cirkensa et al., 1966).

Finally, renal nerves were shown to constitute an important efferent pathway through which acute caval constriction stimulates renal sodium retention (Azer, Gannon and Kaloyanides, 1972). In addition, the natriuretic response to ECV expansion is blunted by high spinal cord section (Pearce and Sonnenberg, 1965) and chronic cardiac denervation (Gilmore and Daggett, 1966; Knox, Davis and Berliner, 1967), while selective preservation of sympathetic efferent pathways or vagotomy do not impair the natriuretic response. This response may therefore be assigned in part to adrenergic efferent pathways of the autonomous nervous system (McDonald et al., 1970).

Regional circulatory alterations in chronic liver disease might well be comparable to those seen in the caval dog. Improvement of renal function in cirrhosis [either spontaneous (Goldstein and Boyle, 1965; Pecikyan et al., 1967) or following cross circulation (Burnell et al., 1967)] as well as functional improvement [following side-to-side rather than end-to-side portocaval shunt (Orloff, 1966; Schröder, Numann and Chamberlain, 1970; Wolfman, Zuidema and Child, 1966)] with restored renal sodium excretion and disappearance of ascites, might be considered in this context as a result of restored intrathoracic haemodynamics. Decreased perfusion of the liver due to portal hypertension may cause haemodynamic alterations with stimulation or suppression of thoracic venous or intracardiac volume-receptors, leading to depression of a humoral natriuretic activity. In analogy to this proposed interrelationship between formation of ascites in liver cirrhosis and renal sodium retention, Cirkensa et al. (1968) concluded, from their experiments in the caval dog, that the differing effects of thoracic and abdominal cava obstruction on proximal tubular sodium resorption suggest that haemodynamic alterations of caval obstruction on hepatic venous or central venous volume may be involved in stimulating or suppressing the production of a humoural factor. A more precise knowledge of the role of such a humoral mechanism, however, must await further investigation.

\section{Acknowledgments}

I gratefully acknowledge the technical assistance of Miss Angela Bäcker and Mrs Dagmar Bean and the secretarial assistance of Mrs Annette Kempf.

\section{References}

Azer, M., Gannon, R. \& Kaloyanides, G.J. (1972) Effea of renal denervation on the antinatriuresis of caval con striction. American Journal of Physiology, 222, 611.

Baez, S., Mazur, A. \& Shorr, E. (1950) Hepatorenal factors in circulatory homeostasis. XX. Antidiuretic action of hepatic vasodepressor VDM (ferritin). American Journal of Physiology, 162, 198.

Baldus, W.P., Feichter, R.N., Summerskill, W.H.J., HuNT, J.C. \& WAKIM, K.G. (1964a) The kidney in cirrhosis. II. Disorders of renal function. Annals of Internal Medicine, 60, 366.

Baldus, W.P., Summerskill, W.H.J., Hunt, J.C. \& Maher, F.T. (1964b) Renal circulation in cirrhosis: observations based on catheterization of the renal vein. Journal of Clinical Investigation, 43, 1090.

Brenner, B.M. \& Troy, J.L. (1971) Postglomerular vascula protein concentration: evidence for a causal role in governing fluid reabsorption and glomerulotubular balance by the rat proximal tubule. Journal of Clinical Investigation, 50 , 336.

Bricker, N.S., Klahr, S., Purkerson, M., Schultze, R.G. Avioli, L.V. \& Birge, S.J. (1968) In vitro assay for a humoural substance present during volume expansion and uraemia. Nature, London, 219, 1058.

Brown, P.R., Koutsaimanis, K.G. \& de Wardener, H.E (1972) Effect of urinary extracts from salt-loaded man on urinary sodium excretion by the rat. Kidney, 2,1 .

Buckalew, V.M. \& LANCASTER, C.D., JR (1971) Studies of a humoral sodium transport inhibitory activity in normal dogs and dogs with ligation of the inferior vena cava. Circulation Research, 28, Suppl. II, 44.

Buckalew, V.M., Martinez, F.J. \& Green, W.E. (1970) The effect of dialysates and ultrafiltrates of plasma of salineloaded dogs on toad bladder sodium transport. Journal of Clinical Investigation, 49, 926.

Burnell, J.M., Dawson, J.K., Epstein, R.B., Gutman, R.A., Leinbach, M.B., Thomas, E.D. \& Volwiler, W (1967) Acute hepatic coma treated by cross-circulation or 
exchange transfusion. New England Journal of Medicine, 276, 935 .

Chaimovitz, C., Szylman, P., Alroy, G. \& Better, O.S. (1972) Mechanism of increased renal tubular sodium reabsorption in cirrhosis. American Journal of Medicine, 52, 198.

Cirkensa, W.J., Dirks, J.H. \& Berliner, R.W. (1966) Effect of thoracic cava obstruction on response of proximal tubule sodium reabsorption to saline infusion. Journal of Clinical Investigation, 45, 179.

Clarkson, E.M. \& DE Wardener, H.E. (1972) Inhibition of sodium and potassium transport in separated renal tubule fragments incubated in extracts of urine obtained from salt-loaded individuals. Clinical Science, 42, 607.

Cort, J.H., Dousa, T., Pliska, V., Lichardus, B., Safarova, J., VRanesic, M. \& Rudinger, J. (1968) Saluretic activity of blood during carotid occlusion in the rat. American Journal of Physiology, 215, 921.

DALY, J.J., ROE, J.W. \& HORROCKS, P. (1967) A comparison on sodium excretion following the infusion of saline into systemic and portal veins in the dog: Evidence for a hepatic role in the control of sodium excretion. Clinical Science, 33, 481 .

de Wardener, H.E., Mills, J.H., Clapham, W.F. \& HayTER, C.J. (1961) Studies on the efferent mechanism of the sodium diuresis which follows the administration of intravenous saline in the dog. Clinical Science, 21, 249.

Epstein, M., Berk, D.P., Hollenberg, N.K., Adams, D.F., Chalmers, T.C., Abrams, H.L. \& Merrill, J.P. (1970) Renal failure in the patient with cirrhosis. The role of active vasoconstriction. American Journal of Medicine, 49, 175.

Gilmore, J.P. \& DagGetT, W.M. (1966) Responses of the chronic cardiac denervated dog to acute volume expansion. American Journal of Physiology, 210, 509.

Gitelman, H.J. \& Blythe, W.B. (1972) Isolation of a natriuretic factor from the posterior pituitary (abstract). Vth International Congress of Nephrology, p. 91.

Goldstein, H. \& Boyle, J.D. (1965) Spontaneous recovery from the hepatorenal syndrome. New England Journal of Medicine, 272, 895.

GoOdyer, A.V.N., Relman, A.S., Lawrason, F.D. \& EPSTEIN, F.M. (1950) Salt retention in cirrhosis of the liver. Journal of Clinical Investigation, 29, 973.

Haberich, F.J., AzIz, O. \& Nowacki, P.E. (1965) Uber einen osmo-receptorisch tätigen Mechanismus in der Leber. Pflügers Archiv für die gesamte Physiologie des Menschen und der Triere, $\mathbf{2 8 5}, \mathbf{7 3}$.

Heacox, R., Harvey, A.M. \& Vander, A.J. (1967) Hepatic inactivation of renin. Circulation Research, 21, 149.

Kaloyanides, G.J. \& Azer, M. (1972) Failure to demonstrate a humoral mechanism in the antinatriuresis of acute caval constriction. Journal of Clinical Investigation, 51, 1297.

Kaloyanides, G.J., Cacciaguida, R.J., Pablo, N.C. \& PorusH, J.G. (1969) Increased sodium reabsorption in the proximal and distal tubule of caval dogs. Journal of Clinical Investigation, 48, 1543.

KNox, F.G., Davis, B.B. \& Berliner, R.W. (1967) Effect of chronic cardiac denervation on renal response to saline infusion. American Journal of Physiology, 213, 174.

KopPel, M.H., CoBurn, J.W., Mims, M.M., Goldstein, H. Boyle, J.D. \& Rubini, M.E. (1969) Transplantation of cadaveric kidneys from patients with hepatorenal syndrome. Evidence for the functional nature of renal failure in advanced liver disease. New England Journal of Medicine, $280,1367$.

KRAMER, H.J. (1972) Humoraler Inhibitor des aktiven Natrium-Transports im Plasma volumen-expandierter Ratten. Proceedings of the VIIIth Symposium on General Nephrology (Ed. by R. Heintz and H. Holzhüter), p. 219. Aachen.
Kramer, H.J. \& Gonick, H.C. (1974) Effect of extracellular volume expansion on renal Na-K-ATPase and cell metabolism. Nephron, 12, 281.

Kramer, H.J., Gonick, H.C. \& Krück, F. (1972) Natriuretisches Hormon. Klinische Wochenschrift, 50, 893.

Kramer, H.J., Gonick, H.C., Paul, W.C. \& Lu, E. (1969) Third factor: inhibitor of Na-K-ATPase? (Abstract). 4th International Congress of Nephrology, Stockholm, p. 373.

Kramer, H.J., Gospodinov, B. \& Krück, F. (1974) Humorale Hemmung des epithelialen Natrium-Transports nach akuter Expansion des Extracellularvolumens. Weitere Untersuchungen zur Existenz eines natriuretischen Hormons. Klinische Wochenschrift, 52, 801.

LAUSON, H.D. (1967) Metabolism of antidiuretic hormone. American Journal of Medicine, 42, 713.

LEVINSKY, N.G. (1966) Nonaldosterone influences on renal sodium transport. Annals of the New York Academy of Sciences, 139, 295.

Lieberman, F.L., Ito, S. \& Reynolds, T.B. (1969) Effective plasma volume in cirrhosis with ascites. Evidence that a decreased value does not account for renal sodium retention, a spontaneous reduction in glomerular filtration rate (GFR), and a fall in GFR during drug induced diuresis. Journal of Clinical Investigation, 48, 975.

Lieberman, F.L. \& ReYnOldS, T.B. (1967) Plasma volume in cirrhosis of the liver: its relation to portal hypertension, ascites, and renal failure. Journal of Clinical Investigation, 46, 1297.

McCloy, R.M., Baldus, W.P., Tauxe, W.N. \& SummerSKILL, W.H.J. (1967) Plasma volume and renal circulatory function in cirrhosis. Annals of Internal Medicine, 66, 307.

McDonald, K.M., Rosenthal, A., Schrier, R.W., GaliCICH, J. \& Lauler, D.P. (1970) Effect of interruption o neural pathways on renal response to volume expansion. American Journal of Physiology, 218, 510.

Milies, E. (1960) A new diuretic factor of hepatic origin Acta Physiologica Latinoamericana, 10, 178.

Mills, I.H., WILSON, R.J. \& DE BONO, E. (1971) The natriuretic activity of renal proteins fractionated by ammonium sulphate precipitation. Journal of Endocrinology, 51, xix.

Mondon, C.E., Burton, S.D. \& Ishida, T. (1969) Functional status of isolated rat kidney perfused in combination with isolated liver. Clinical Research, 17, 168.

OrLOFF, M.J. (1966) Effect of side-to-side portocaval shunt on intractable ascites, sodium extraction and aldosterone metabolism in man. American Journal of Surgery, 112, 287.

PAPPER, S. (1973) The kidney in liver disease. In: Diseases of the Kidney (Ed. by M. D. Strauss and L. G. Welt), p. 841 . Little, Brown, Boston.

PAPPER, S. \& VAAMONDE, C.A. (1968) Renal failure in cirrhosis-role of plasma volume. Annals of Internal Medicine, 68, 958.

Pearce, J.W. \& Sonnenberg, H. (1965) Effects of spinal section and renal denervation on the renal response to blood volume expansion. Canadian Journal of Physiolog. and Pharmacology, 43, 211.

Pecikyan, R., Kanzaki, G. \& Berger, E.Y. (1967) Electrolyte excretion during the spontaneous recovery from the ascitic phase of cirrhosis of the liver. American Journal of Medicine, 42, 359.

Quamme, G., Dirks, H. \& Friesen, H.G. (1973) Natriuretic effects of posterior pituitary extracts in rats. Clinical Research, 21, 703.

Robinson, A.G., Michelis, M.F., Warms, P.C. \& Davis, B.B. (1973) Natriuretic effect of posterior pituitary neurophysin. Clinical Research, 21, 501.

Robson, A.M , TATEishi, S., TAggart, D.D. \& Bricker, N.S. (1969) A humoral inhibitor of sodium transport in the serum of volume expanded dogs. Abstracts. The American Society of Nephrology (IIIrd Annual Meeting), p. 57 
Salomon, M., Sakaguchi, H., Churg, J., Dachs, S., Grishman, E., Mautner, W, Paronetto, F. \& RosenTHAL, W.S. (1965) Renal lesions in hepatic disease. Archives of Internal Medicine, 115, 704.

SCHRier, R.W., Humphreys, M.H., UfFman, R.C. \& EARLEY, L.E. (1971) Afferent and efferent mechanisms involved in the antinatriuretic effect of acute constriction of the thoracic vena cava. Clinical Research, 19, 154.

SCHRIER, R.W. \& DE WARDENER, H.E. (1971) Tubular reabsorption of sodium ion. New England Journal of Medicine, 285, 1231.

Schröder, E.T., Numann, P.J. \& Chamberlain, B.E. (1970) Functional renal failure in cirrhosis. Recovery after portocaval shunt. Annals of Internal Medicine, 72, 923.

Schröder, E.T., Shear, L., Sancetta, S.M. \& Gabuzda, G.J. (1967) Renal failure in patients with cirrhosis of the liver. III. Evaluation of intrarenal blood flow by paraaminohippurate extraction and response to angiotensin. American Journal of Medicine, 43, 887.

Sealey, J.E. \& Laragh, J.H. (1971) Further studies of a natriuretic substance occurring in human urine and plasma. Circulation Research, 28, Suppl. II, 32.

SMith, H.W. (1957) Salt and water volume receptors: An exercise in physiologic apologetics. American Journal of Medicine, 23, 623.

Stahl, J., JahN, H., Jahn, M. \& Kieny, R. (1967) Preuve en faveur de l'origine hépatique de l'activité diurétique et natriurétique décélée chez l'homme et le chien au cours de l'expansion du volume extracellulaire et de la stimulation des volorécepteurs intrathoraciques. Compte rendu hébdomadaire des séances de l'Académie des Sciences, Paris, 265, 1240.

Strandhoy, J.W \& Williamson, H.E. (1970) Evidence for an hepatic role in the control of sodium excretion. Proceedings of the Society for Experimental Biology and Medicine, 133, 419.
SummerskiLl, W.H.J. (1966) Hepatic failure and the kidney. Gastroenterology, 51, 94.

Traverso, H.D., Raynaud, C., Blanchon, P., Roberti, A., Vesin, P. \& Viguie, R. (1966) Etude des clearances de l'inuline et du PAH, du débit cardiaque, du $\mathrm{Na}$ et du $\mathrm{K}$ échangeables et des 'liquides extracellulaires' au cours de l'évolution de la cirrhose du foie. Revue internationale d'hépatologie, 16, 137.

Tristiani, F.E. \& COHN, J.N. (1967) Systemic and renal hemodynamics in oliguric hepatic failure: effect of volume expansion. Journal of Clinical Investigation, 46, 1894.

Vaamonde, C.A., Vaamonde, L.A., Presser, J.I., Morpi, H.J., Klinger, E.L. \& PAPPer, S. (1971) The role of vasopressin and urea in the renal concentrating defect of patients with cirrhosis of the liver. Clinical Science, 41, 441.

VEsin, P. (1972) L'insuffisance rénale fonctionnelle du cir- $\frac{0}{0}$ rhotique. Evolution, mécanisme, traitement. Archives des maladies de l'appareil digestif et de la nutrition, 61, 775.

Wernze, H., Seki, A., Schneider, K.W \& Jesse, R. (1972) v Hepatische Extraktion und Clearance von Renin bei Lebercirrhosen. Klinische Wochenschrift, 50, 302.

Wolff, H.P., Bette, L., Blaise, H., Düsterdieck, G., Janecke, J., Kobayashi, T., KRÜck, F., Lommer, D. \& SCHIEFFER, H. (1966) Role of aldosterone in edema formation. Annals of the New York Academy of Sciences, 139, 285.

Wolfman, E.F., Zuidema, G.D. \& Child, C.G. (1966) Urine sodium and aldosterone excretion following portocaval shunts in cirrhosis of liver and portal hypertension: Effect of end-to-side and side-to-side anastomoses in $16 \stackrel{\omega}{\rightarrow}$ cases. Annals of Surgery, 164, 538.

Wollheim, E. (1951) Kreislauf und Wasserhaushalt Hepatitis-der Sechs-Stunden-Wasserversuch als Lebef funktions prüfung. Deutsche medizinische Wochenschris 76, 789 . 